\title{
SOCIAL CHANGES IN RURAL AREAS: INCOMES AND EXPENDITURES OF RURAL HOUSEHOLDS
}

\author{
Pawet Chmieliński ${ }^{1}$, Barbara Chmielewska ${ }^{2}$
}

\begin{abstract}
Summary
In the study we analyse changes in the level and structure of income and expenditure of households in rural and urban areas during the period of Polish integration with the European Union. This allows to answer the question of whether and how the social distance divides the residents of the rural and urban areas. The results showed improvement in economic and social situation in the rural areas. The living gap between rural residents and urban residents decreased. In the structure of incomes of rural households, the share of income from non-agricultural sources increased and at the same time the share of expenditure on food in total expenditure was smaller. However, the differences are still significant. The challenge for rural development policy is to reduce the gap between rural and urban areas, especially in terms of quality of life. This requires further development of non-agricultural jobs in rural areas.
\end{abstract}

Keywords: incomes, consumption, rural households, rural areas, Poland

JEL: Q12, O18, D11

\section{Introduction}

In the past, numerous researchers perceived rural areas mainly from the viewpoint of agriculture and food economy. They focused on agriculture and their research concerned, above all, land use, agrarian structure, labour input and structure of agricultural production. There were also studies on demographic problems (Stasiak, 1983). A special place in the contemporary rural research is reserved for research of social space, in particular conditions and standards of life of social groups and the term "rural" is increasingly often interpreted as the world of social, moral and cultural phenomena and processes involving rural residents (Wójcik, 2009).

1 Paweł Chmieliński Ph.D., Assistant Professor, Institute of Agricultural and Food Economics - National Research Institute, Świętokrzyska street no. 20, 00-002 Warszawa, Poland, Phone: +482 25054 774; E-mail: chmielinski@,ierigz.waw.pl

2 Barbara Chmielewska Ph.D., Associate Professor, Institute of Agricultural and Food Economics - National Research Institute, Świętokrzyska street no. 20, 00-002 Warszawa, Poland, E-mail: chmielewska@,ierigz.waw.pl

EP 2015 (62) 4 (907-920) 
In Great Britain, there is even a vision of "rural idyll" expressing longing of a modern man for a harmonious life in a friendly natural and social environment, close to nature and rich in everyday human relations. Unfortunately, the idyllic image of the rural areas is often contrasted with the peripheral rural areas characterised by population aging, migration outflow, social exclusion, anti-social behaviours, poverty and lack of development perspectives (Bański, 2014). Popularisation of transport, tourism and leisure increased interest in economic and social problems of rural areas. What definitely increased, was the interest in the problems of rural population and rural development covering such issues as residential construction, transport, access to water supply and sewage systems, leisure time and environmental protection. The rural areas today form a complex system of interconnected natural, social and economic elements, as well as (or rather, first of all) a place of work and life of humans (Bański, 2014, Sikorska et al., 2009). Thus, science also asks which societies form rural areas, and how rural space is perceived (Philips, 1998).

The presented research aims in analysis of the change in the economic situation and, consequently, social situation of rural population and its comparison to the situation of urban residents. We attempt to answer the following questions: How deep is the socio-economic gap between the rural and urban residents in terms of incomes and consumption? Which households, farming or non-farming families, form the contemporary rural economy? What changed in this scope as a result of Poland's accession to the European Union?

The analysis was conducted primaly on the basis of empirical data from Polish Central Statistical Office's household budgets survey. As the basic determinant of economic and social situation of the population the study adopts the level and structure of household expenditure on urban and rural areas and then, on the basis of changes in the level and structure of expenditure, assessed the changes in their social situation over the period of Poland's integration with the European Union. A research of the change in the structure of expenditure was also used to assess the phenomena of social inequalities.

\section{Perception of rural space and characteristics of labour market}

The rural issues are dealt with by various disciplines - geography, sociology, agricultural sciences, economy, ethnography and anthropology - which makes it rather difficult to define the term rural areas (the countryside). There are many definitions and each of them describes the term from a different perspective. Another difficulty is the fact that apart from science, different state offices and international organisations dealing with planning, development strategies, spatial policy and collection of statistical materials have their own definitions of rural areas. Statistical offices play a special role among them since they collect data according to internally defined units. The Polish statistics of the Central Statistical Office (CSO) apply the administrative criterion: rural areas cover all territories located outside of administrative boundaries of cities. They include territories bordering on large urban agglomerations which, practically, completely lost their rurality and, as regards most of the socio-economic features, rather resemble cities 
(CSO, 2013c). On the other hand, international statistics define rural areas as territories with the population density below 150 person per $\mathrm{km}^{2}$.

Rural areas are marked by a number of physical and socio-economic features including: low density of population and development, landscape predominated by open green spaces, "surface" economic activity mainly of agricultural and forestry functions, lifestyle of residents predetermined by affiliation to a small social group and identify and appearance of the population deeply rooted in distinctive peasant culture. The two last features clearly refer to the social dimension of rural areas (Kayser, 1983; Bański, 2014). Initially, the term "rural" was equated with a certain space of extensive land use and low population density. The contemporary rural studies focus on a rural resident and rurality is viewed from the perspective of a set of social, moral and cultural features. This may cover a sense of belonging to a local community, traditions and customs, attachment to land or a conviction that one lives in the countryside. The literature on the subject indicates that homogeneous rural space no longer exist, what we have is a multitude of interpenetrating social spaces. The the very concept of rural areas also shows a marked variation over time (Cloke, Milbourne, 1992).

Regular people usually have no problems with differentiating urban areas from rural areas. Rural areas are usually associated with farmlands and farms, as well as a place to stay for a summer holiday or to go to for a weekend trip. Although rural areas are more and more alike urban areas in social and infrastructural terms, farm users are still different from urban residents as regards their behaviour, sense of community spirit, greater piousness.

Rural development in Poland is largely conditioned by the pace of changes taking place in agriculture which result in a loss of rural population working permanently on a fulltime basis at a farm. Hence one of the basic priorities of development is strengthening of the residual function of rural areas, i.e. supporting the transformation of rural areas into attractive place of life and work of the local communities. The research of the IAFENRI (Karwat-Woźniak, Chmieliński, 2013) shows that the social and living situation of a growing number of rural residents is dependent on the possibilities of earning. Rural labour market is not able to ensure employment to all rural residents. Thus in this group it is common that people working in non-agricultural professions commute.

According to the data from the IAFE-NRI, the predominance of urban enterprises is increasingly clearly outlined in the employment structure of rural population. At the same time, urban areas are a more important, from the perspective of demand for labour, place of employment of persons from non-farming families, than those linked to farming. However, recently there has been a marked increase in earning of people from farming families, since diversification of sources of livelihood gives an opportunity to increase the use of labour resources and improve the economic and living situation of the rural population, especially for families using farms of small area and characterised by small scale of commodity production and producing mainly for subsistence needs. Growing professionalization, usually in case of farms of larger area whose income is 
at least at parity level, is linked to an increasing share of labour-saving methods of production and a greater number of technical devices to support labour. This results in a greater number of redundant people at a farm. Because the number of unused labour resources in farming families grows, more and more people decide to seek employment opportunities outside of agriculture. At the same time, taking up a job is not usually linked to a change of the place of residence, thus this decision largely depends on the situation on the local labour market and the possibility to commute.

Improvement of the intersectoral mobility of rural labour resources and thereby the improvement of the socio-economic structure of the rural population, should cover aiming at rationalisation of the structure of its members and beneficiaries, also support for professional re-qualification of the population linked to using a farm (Sikorska et al., 2009).

Because the proposed shape of the Rural Development Programme 2014-2020 (2014) assumes support for socio-economic rural development, with special emphasis to pro-effective changes in agriculture, the development of basic social and technical infrastructure on rural areas depends largely on the extent to which these problems are included in the cohesion policy instruments. Still, the significant gap between the development of rural and urban areas is reflected in the quality of life on these areas, and affects the development of local labour markets, as well as the possibility of increasing the circular mobility of the rural residents. Research of the IAFE-NRI points to a trend, among the rural population taking up job outside of their place of residence, to seek work in cities located at a distance of not more than $20 \mathrm{~km}$. The exception are rural areas situated in the range of impact of large cities (especially voivodeship cities), where people are willing to commute even at a distance of up to $100 \mathrm{~km}$.

Circular economic migrations are an important phenomenon that will have a direct impact on the level of economic infrastructure development of rural areas. In 2010, the average number of working rural residents amounted, according to LFS, to 6,082 thousand, out of which 3,453 thousand persons, i.e. 56.8\% commuted (CSO, 2011a). Due to support in the form of aid funds the scale of investment in road infrastructure increased, which contributed to the improvement of roads in the recent years and shortening of the travel time. This is reflected in the increase in the number of commuters in the total number of working people. Between 2008 and 2010 the number of rural residents commuting increased by 131 thousand. Among all people earning in Poland, who worked outside of their place of residence, in 2010 rural residents constituted $33.5 \%$ and this was by 2 p.p. more than in 2008 .

Spatial range of a labour market for rural residents is defined by the distance covered by rural residents on their way to job. Both surveys and mass statistics confirm that a definite majority of rural residents working outside of their place of residence commuted on a distance below $20 \mathrm{~km}$. This suggests that the average labour market for rural residents comprises enterprises situated on the area of a gmina, relatively voivodeship, on the area of which is the person's village. The only exception are villages situated 
near administrative boundaries, for which the local labour market goes beyond the established territorial boundaries. Border traffic works under the same rules and after Poland's accession to the Schengen Agreement opportunities for free movement and employment on the territory of most European Union countries have been created. The research of IAFE-NRI shows that circular mobility of residents of villages situated near boundaries with the EU countries, mainly Germany, is common (Chmieliński, 2013). Residents of such villages may be active on the foreign labour markets not changing their place of residence.

Information about the spatial range of local labour markets, calculated as the average distance to the workplace are confirmed by the LFS data from 2010, according to which of those working outside of their place of residence 96.5\% worked at enterprises located on the area of the voivodeship of their residence. In the geographic structure of the labour market, companies from the area of a gmina of commuters' residence are essential as it comes to demand for labour, as they were inhabited by $56.1 \%$ of all people working outside the village of their residence.

The time of commuting is an important criterion of activity on the local labour market. As it has already been mentioned, because of positive changes in infrastructure it is possible to seek a job in companies more and more distant from the place of residence. There occurs a common change in the perception of physical distance which is assessed not only by the criterion of distance travelled, but also the time of travelling. Among commuters $70 \%$ covered no more than $20 \mathrm{~km}$ and needed nearly the same number of minutes to cover the distance, i.e. it took them less than 30 minutes. According to the research of IAFE- NRI, conducted in 2011, most of the people working outside of their place of residence lived at a distance from their workplace that could be covered, on average, in 18 minutes.

"Localness" of rural labour markets may be understood literally since their territorial range largely covers the territory of a gmina and neighbouring gminas and for the majority of people working outside of their place of residence it closes within the boundaries of a voivodeship. The key factor in selecting a place of earning is the travelling time. When there is still an insufficient number of jobs in the place of residence the size of the local labour market will be determined by the condition of road infrastructure, and quality of services of public transport companies. The time of commuting and to public utility facilities gains in importance as a factor in rural development offsetting the shortages in infrastructure development within rural areas.

\section{Diversity of conditions and standard of life in rural and urban areas}

Despite many years of cohesion activities introduced and implemented by subsequent governments, there is still a wide gap between the life standard in Poland's rural and urban areas, and the former continue to be a rather incoherent economic, social and cultural conglomerate. This is primarily the result of still vivid imprint of historical events, but also uneven distribution of accents in individual rural and agricultural 
development strategies implemented over the last several dozen years. Yet, it needs to be very strongly emphasised that the scale of changes taking place on rural areas, in particular in the last decade, is of unprecedented intensity (Hałasiewicz).

In Poland, there is a quite common belief that the greatest socio-economic transformations on the rural areas took place after Poland's integration with the European Union. In this light a question comes to mind: to what extent are these changes even? or maybe they rather result in further economic and social polarisation of the Polish countryside? What draws attention in the first place is the fact that the Polish rural areas for years undergoe deagrarization, understood as a decline in the importance of agriculture for the rural economy and local communities and rural culture. Thus it is impossible to understand the transformations occurring on Poland's rural areas without considering the scale and significance of the phenomenon. As a result, it is especially important to consider the high level of heterogenization of employment structure in rural economy, as well as in the rural social structure.

The change in the structure of income is one of the manifestations of the changes in the employment structure (Table 1).

Table 1. Sources of income in urban and rural households (\%)

\begin{tabular}{|l|r|r|r|r|}
\hline \multirow{2}{*}{ Specification } & \multicolumn{3}{|l|}{ Rural areas } & \multicolumn{2}{l|}{ Urban areas } \\
\cline { 2 - 5 } & $\mathbf{2 0 0 6}$ & $\mathbf{2 0 1 2}$ & $\mathbf{2 0 0 6}$ & $\mathbf{2 0 1 2}$ \\
\hline Total disposable income & 100.0 & 100.0 & 100.0 & 100.0 \\
\hline income from paid employment & 39.4 & 47.2 & 51.1 & 56.6 \\
\hline income from self-employment & 6.1 & 7.6 & 9.5 & 8.9 \\
\hline income from individual farms in agriculture & 14.1 & 12.6 & 0.5 & 0.3 \\
\hline income from social benefits and insurance & 29.7 & 24.8 & 27.7 & 26.0 \\
\hline income from other social benefits & 6.2 & 4.1 & 4.8 & 2.9 \\
\hline
\end{tabular}

Source: CSO, 2007; CSO, 2013.

Increase in the share of income from non-agricultural work and simultaneous drop in the share of income from agriculture, is especially visible in the change of structure of rural community's income, as it additionally points to the process of deagrarization of rural areas. However, disturbing is the increase in the share of income from social assistance benefits, which may be interpreted as a sign of spreading poverty and social polarisation on rural areas.

The income of households is also one of the key criteria of assessment of socio-economic processes taking place on rural areas. Not only the level, but also the relations between different social groups are important. In the period of accession the income gap between urban and rural population has narrowed. In the first years after the accession (in 2006), the average monthly disposable income per capita in an average urban household was higher than the income on rural areas by 43.2\% (PLN 943.90 on urban areas against PLN 659.29 on rural areas). After a few years the advantage decreased in 2012 to 40.1\% (PLN 1,439.54 on urban areas against PLN 1,027.63 on rural areas). Although the general income gap is still significant, a high drop in the difference between income 
from self-employment should be emphasised (in parallel from 123.5\% to 62.8\%). A decrease in the difference was also noted in the income from paid employment (from $85.8 \%$ to $67.8 \%$ ). These changes allow to conclude that the diversification of sources of livelihood of rural residents has increased which is, undoubtedly, reflected in the change in the social structure on rural areas. Increasingly more non-farmers settle on rural areas.

At the same time, an increase in the advantage of income from an individual farm in an average rural household per capita against an average urban household was noted. In 2006-2012, this advantage increased from 20 times to 34 times. It may be concluded, that a group of larger, better developed and more profitable farms clearly separates on rural areas. And urban population increasingly less supplements their budgets with income from allotment gardens, probably, more often using them for recreational purposes.

The lower level of income of rural population is accompanied by a wider range and greater risk of poverty as compared to urban population. Moreover, the lower level of income of rural population combined with greater difficulties on the rural labour market compared to the urban one, and infrastructural barriers on rural areas constitute a real threat of increase in the level of poverty and deepening development gap along the rural-urban line (CSO, 2011b; Kaleta 1999). In 2012, the poverty risk indicator was at the level of $12.3 \%$ on urban areas, while on rural areas it was by nearly twofold higher and amounted to $24.3 \%$. Similarly, the indicator of poverty or social exclusion risk was significantly lower on urban areas than on rural areas (22.7\% against $32.8 \%)$. Also as regards other basic indicators, set by the "Europe 2020" strategy, urban population was characterised by better socio-economic situation than rural population, but the gaps were in their case slightly more narrow. The indicator of severe material deprivation amounted on urban areas to $13.0 \%$, while on rural areas to $14.2 \%$, and the indicator of low labour intensity was alike: $7.3 \%$ against $6.2 \%$ (CSO, 2013a).

Significant differences between urban and rural areas were also noted in the subjective assessment of the material situation. In 2012, 2.5\% of urban households assessed their material situation as "very good", while in case of rural areas it was only $1.0 \%$. Similarly higher share of urban households assessed their material situation as "rather good" $(22.1 \%)$ than of rural households (16.9\%). On rural areas there was, however, more households than on urban areas that considered their material situation as "average" (59.9\% against $55.1 \%)$ and "rather bad" (16.1\% against $13.6 \%)$ (CSO, 2013b).

\section{Change in the level and structure of expenditure}

Literature on the subject usually names income as the basic determinant of differentiation, mainly, economic, but following from it also social. Apart from it, conditions and standards of life are increasingly often assessed on the basis of the level and structure of expenditure on consumption and not income. It is hence assumed that expenditure are more reliable than income declared by the family, for instance, because they are characterised by probably lower degree of underestimation. The level and structure 
of expenditure may be taken, although with some simplification, as an illustration of the gap in the life standard between urban and rural families, and a pattern of their consumption, thereby social gap between urban and rural areas. However, it should be kept in mind that neither the life standard nor the consumption patter follow entirely from economic situation of a family (although they are primarily a derivative of the volume of income), they are also shaped by subjectivism and cultural and climatic conditions which differentiate between the costs of some needs.

The level of income is the basic determinant of the level and structure of expenditure and thus the possibility to satisfy the needs of households. Low income allows to satisfy the primary needs essential to life, i.e. to follow the consumption pattern indicating the satisfaction of primary needs. Along with an increase in income of a household the scope of satisfied needs extends with the needs of a higher level, which means following a consumption pattern indicating the satisfaction of secondary needs or needs described as luxurious. Primary needs include, above all, food, as well as clothing, housing and health care. Whereas, needs in the field of education, culture, entertainment are secondary needs satisfied only after the basic needs are met to, at least, adequate degree. Hence there is a regularity, which shows that as the income increases, the share of expenditure on food decreases, the share of expenditure on rent, fuel and clothing is relatively constant, while the share of secondary expenditure grows ${ }^{3}$. High share of expenditure on food in total expenditure points to following a consumption pattern based on satisfaction of primary needs. Whereas, a decreasing share of expenditure on food in the total expenditure along with simultaneous increase in the share of expenditure on non-food goods informs on following the consumption pattern of increasingly higher level than the primary (secondary or luxurious), which indicates a gradual improvement in the living conditions of a family (Kołodziejek, Zielińska, 1989). Table 2 illustrates the changes in the level and structure of expenditure.

In the period of Poland's accession to the European Union there occurred multidirectional, oscillating, positive and negative changes both on rural and urban areas in the level and structure of funds allocated to satisfaction of needs. Nonetheless comparison of the manner of allocation of funds intended for consumption by the average urban and rural household enables to identify certain social trends.

3 Engel's law defines the interdependencies between income and structure of expenditure of the population. 
Table 2. Changes in the level and structure of expenditure in urban and rural households in the period of Poland's accession to the European Union

\begin{tabular}{|c|c|c|c|c|}
\hline \multirow{2}{*}{ Specification } & \multicolumn{2}{|c|}{$\begin{array}{c}\text { Relation of urban/rural } \\
\text { expenditure level } \\
\% \\
\end{array}$} & \multicolumn{2}{|c|}{$\begin{array}{c}\text { Change in expenditure } \\
\text { structure in 2006-2012 } \\
\text { percentage points }\end{array}$} \\
\hline & 2006 & 2012 & rural areas & urban areas \\
\hline Total expenditure & 138.6 & 136.5 & $\mathrm{x}$ & $\mathrm{x}$ \\
\hline food and non-alcoholic beverages & 108.0 & 110.9 & -3.2 & -1.6 \\
\hline alcoholic beverages and tobacco products & 137.4 & 144.7 & -0.1 & 0.1 \\
\hline clothing and footwear & 145.1 & 142.2 & -0.4 & -0.5 \\
\hline housing and energy carriers & 150.5 & 144.9 & 0.9 & 0.5 \\
\hline flat equipment and running a household & 137.5 & 139.4 & -0.4 & -0.3 \\
\hline health & 148.4 & 151.6 & 0.0 & 0.2 \\
\hline transport & 118.5 & 118.7 & 1.0 & 1.0 \\
\hline communication & 158.7 & 135.4 & -0.7 & -1.4 \\
\hline leisure and culture & 218.6 & 185.3 & 1.4 & 0.8 \\
\hline education & 236.5 & 220.8 & 0.1 & -0.3 \\
\hline restaurants and hotels & 260.3 & 247.4 & 0.6 & 1.0 \\
\hline other goods and services & 163.3 & 156.4 & 0.2 & 0.0 \\
\hline pocket money & 119.6 & 76.9 & 1.1 & 0.2 \\
\hline other expenditure & 152.0 & 165.6 & 0.3 & 0.1 \\
\hline
\end{tabular}

Source: CSO, 2007; CSO, 2013.

First of all, what decreased was the advantage of the average monthly values per capita of expenditure of urban households compared with the expenditure of rural households from 38.6\% in 2006 (PLN 833.96 on urban areas to PLN 601.64 on rural areas) to 36.5\% in 2012 (PLN 1,173.81 on urban areas to PLN 859.23 rural areas). The gap in the total expenditure of households between urban areas and rural areas was smaller than in the case of income. It may be suggested that rural families tried to "catch up" with the life standard of urban families and spent money instead of saving it. Attention is, however, drawn to a very significant differentiation as regards individual targets. The greatest differences were noted in case of secondary expenditure. These included expenditure on: "leisure and culture", "education" and "restaurants and hotels". This points to significant social inequalities between urban and rural residents to the disadvantage of the latter. In the period of the accession the gap, indeed, narrowed but the differences are still high. Narrowing the gap between these categories of expenditure may result both from a positive change in the mentality of rural families towards a wider use of goods that were previously used mainly by the urban population, as well as from an increase in migration from cities to rural areas. Also changes in the case of expenditure for pocket money may be considered as greater "openness" to independence of members of rural families.

The increase in the advantage of expenditure on alcoholic beverages and tobacco products of urban families as compared to rural ones is also interesting. This may be interpreted not only as a success of comprehensive health promotion campaigns and common sense 
behaviour, but above all as the acceptance of a new lifestyle of rural families, especially agricultural ones, because they always demonstrated the highest share of expenditure on alcohol as compared to other social and professional groups of households.

Another positive trend is narrowing of the gap between urban and rural areas as regards expenditure on education which gives the grounds for social and professional success. Doubts, however, arise due the fact that rural areas probably own this positive accent to rural non-agricultural community, since in the period of accession the share of expenditure on this target decreased in the households of farmers (Chmielewska 2013). This group of expenditure, significant for mental and physical development of the young generation and its position on the labour market, always constituted a small share in the households of farmers. In the future, expenditure on education may decide on the social situation of families of farmers and conditions of career start of their children. Unfortunately, research results provided by other research centres give the lack of money as the main reason for limiting expenditure on education, because the awareness and aspirations of farmers regarding education of their children have improved significantly after Poland's accession to the European Union. As far as in 2003 , as much as $26.0 \%$ of farmers considered that primary education of their child is sufficient, already in 2009 merely $9.6 \%$ wanted their children to graduate only from a vocational school; while $33.9 \%$ - wanted their children to graduate from a technical college or vocational high school, and the most of them, i.e. $68.3 \%$ - wanted their children to get a university degree (Master's degree) (Social Diagnosis 2003, Social Diagnosis 2009).

Given the overall improvement of the well-being of rural families in the period of Poland's membership in the European Union (e.g. due to direct payments) it may be assumed that there are three types of possibilities of limiting expenditure on education, namely: (1) raising the level of education gives way to other needs in the ranking of resources allocated to non-food purposes; (2) the costs of education (tuition, fees for lodgings or costs and hardships of transport and purchase of school aids) are so high that they become the cause of resignation from skills improvement; (3) the adverse demographic changes, such as, above all, decrease in the share of people in the preworking age in the structure of rural family, including as a result of economic migration of young people after Poland's accession to the European Union.

Analysis of changes in the relation of expenditure between urban and rural areas requires to ask a question: do the changes in mutual disproportions of expenditure on individual needs correspond to the improvement of satisfaction thereof? Doubts may arise primarily as regards the increase in the advantage of expenditure on urban areas on such target as health. High expenditure on health probably does not follow from greater attention to preventive healthcare, but results from a growth in the prices of medicines and medical services, including development of private medical clinics ${ }^{4}$. Deterioration in the relation of expenditure of rural residents as compared to urban

4 In 2000-2010, the prices of pharmaceuticals increased by $36.3 \%$; while that of outpatient services by $37.6 \%$. According to: CSO, 2011, p. 440. 
residents on healthcare may point to a failure to met many needs in this regard by the rural population. Additionally, farmers are characterised by "competition" between consumption targets of households and production targets of farms, which may contribute to limiting expenditure on household needs.

Analysis of the changes in the level and structure of expenditure of urban and rural households allows to conclude that in the period of Poland's integration with the European Union the economic and social gap between urban and rural residents has narrowed. The conditions and standards of life of rural population have improved as indicated by the positive changes in the structure of their expenditure, especially the drop in the share of total expenditure on food and simultaneous increase in the share of expenditure on secondary aims.

\section{Conclusions}

The research conducted on the basis of assuming as the indicators of social changes on rural areas the changes in the level and structure of expenditure in the context of urban/rural relations, although does not allow to capture the full range of changes taking place on the contemporary rural areas it at least allows to point some trends in therein. First of all, it is possible to note an improvement in the socio-economic situation on rural areas and the narrowing of the gap between the standards of life of rural and urban residents. These changes result from both an improvement of income situation of rural population (including farmers), as well as migration processes and suburbanisation, deagrarization of rural communities and rural economy as well as increase in the significance of natural resources conservation. This is manifested, for example, in convergence of consumption patterns of rural and urban communities, but the differences are still quite clear.

Achallenge for rural development policy (rural areas) is further narrowing of the gap between rural and urban areas, mainly as regards quality of life. These activities should not, however, result in loss of the value added following from the cultural and social differentiation of rural areas constituting per se one of the more important development niches.

A change in the structure of income points to the fact that over the last years there emerges a process of growing level of off-farm employment of rural residents. At present, the agricultural function is not able to ensure decent income to rural residents. It is expected that in the future the demand for work in the sector will further decrease. This, at the same time, means that it is necessary to develop non-agricultural functions on rural areas, such as e.g. tourism, services, trade, small-scale production, housing. It will allow to narrow the socio-economic gap between rural and urban areas. At the same time, it will be linked to the progress of the rural deagrarization process. The perspective of departing from the rural character of rural areas and shift the emphasis towards non-agricultural functions may affect designing of rural policy in Poland, in which the issues of non-farming population may become more important than the problems of farmers. 
The direction of socio-economic changes that took place on the rural areas in the period after the accession indicates that the correct development of social and economic life on rural areas will require to create better access to labour markets for rural residents. To this end, regular and coordinated activities will be needed to raise the qualifications of rural residents, especially of the young generation. This will enable to take up job offers of the contemporary labour market. It is also advisable to develop communication systems, including electronic communication thereby facilitating paid employment or self-employment to rural residents without the need to leave their place of residence.

Diversification of rural economy is rightly considered as the solution to problems with rural development. The present trends of rapid development in some agglomerations and their closest surroundings to some extent hinders entrepreneurship development on areas of inferior location. This situation should be connected to the fact that rural areas are devoid of service background and characterised by insufficiently qualified labour force and lack of industrial heritage. For that reason some part of rural areas will be doomed to relatively slow development.

Speeding up multidirectional development of rural areas is linked to the emergence of many factors, especially: individual entrepreneurship of residents, activity of local authorities, good advisory for business entities, relevant schooling of residents and comprehensive development of infrastructure.

Under the conditions of growing importance of non-agricultural professional activity of rural residents, the future of rural development in Poland will be closely linked to strengthening the residential functions of the village, whose importance will grow along with the development of communication infrastructure and utilities, determining the quality of life on the rural areas. Research shows that the sizes of the labour market will be limited not by distance, but by the time of commuting. The development of infrastructure not only hinders the process of migration of rural residents to urban areas but also strengthens reverse trends - inflow of urban residents to rural areas (but still primarily to places situated near an agglomeration or by the main communication routes) and increase in the level of spatial circular mobility. The phenomenon of circular migration of rural residents will still progress along with an increase in the level of educational attainment, while the decisions on permanent migration will depend on the difference in the quality of life between the rural areas and urban agglomerations. This points to convergence of the lifestyle of the residents of these areas. Along with access to mass information, unification of life and consumption patterns the aspirations of these groups become similar. Consequently, the scope of needs considered as basic changes. Their scope not only covers satisfaction of living needs (i.e. basic trade and service infrastructure), but also access to cultural and entertainment offer, healthcare and specialist services. Shortcomings in the development of rural infrastructure may be offset by development of road infrastructure and public transport systems only to some degree. Infrastructural investment would allow for extension of the range of impact of economic development centres (located in urban agglomerations) and to mitigate the effects of structural unemployment on rural areas. 


\section{References}

1. Bański J., (2011): Wieś w badaniach geograficznych - ewolucja badań i przeglad koncepcji obszaru wiejskiego. in Wieś jako przedmiot badań naukowych na początku XXI wieku. M. Halamska (ed.). Warszawa: Wydaw. Nauk. Scholar, pp. 29-44.

2. Chmielewska B., (2013): Ekonomiczno-społeczna sytuacja gospodarstw domowych rolników po akcesji Polski do Unii Europejskiej, SiM nr 158, IERiGŻPIB, Warszawa, p. 207.

3. Chmieliński P., (2013): Ludność wiejska na rynkupracy. Zarobkowanie, bezrobocie, przedsiębiorczość i praca za granicq w latach 2005 - 2011. A. Sikorska (ed.), Warszawa, IERiGŻ-PIB.

4. Cloke P., Milbourne P. (1992): Deprivation and lifestyles in rural Wales II: rurality and the cultural dimension, Journal of Rural Studies, No. 8, pp 359-371.

5. CSO (2007): Budżety gospodarstw domowych w $2006 r$. GUS, Warszawa.

6. CSO (2011a): Informacja o rozmiarach i kierunkach emigracji z Polski w latach 2004-2010, Warszawa, GUS.

7. CSO (2011b): Obszary wiejskie w Polsce, Warszawa, Olsztyn, GUS.

8. CSO (2011c): Rocznik Statystyczny 2011. Warszawa,GUS, 440.

9. CSO (2013a): Europejskie badanie dochodów $i$ warunków życia (EU-SILC) w 2012 r., GUS, Warszawa.

10. CSO (2013b): Budzety gospodarstw domowych w $2012 r$. GUS, Warszawa.

11. CSO (2013c): Rocznik Statystyczny 2012. Warszawa,GUS.

12. Hałasiewicz A. (2014): Rozwój obszarów wiejskich w kontekście zróżnicowań przestrzennych w Polsce i budowania spójności terytorialnej kraju, ekspertyza dla MRiRW, maszynopis, 3. www.minrol.gov.pl/rozwój_regionalny/Ewaluacja, (accessed at: 16.06.2014)

13. Kaleta A. (1999): Rewitalizacja obszarów wiejskich Europy, t. I, WrocławWarszawa

14. Karwat-Woźniak B., Chmieliński P. (2013): Ludność wiejska oraz jej aktywność zawodowa isytuacja na rynku pracy in: Rynek pracy wobec zmian demograficznych, M. Kiełkowska (ed.), Zeszyty demograficzne, Instytut Obywatelski, Warszawa, pp. 64-93.

15. Kayser B. (1983): Le village recompose, pour l'analyse du changemant social et cultural en milieu rural, GEODOC, Toulouse, p. 27.

16. Kołodziejek B., Zielińska Z. (1989): Potrzeby i spożycie. Warszawa, PWE, pp. 43-44.

17. Phillips M. (1998): Social perspectives in: The geography of rural change, B. Ilbery (ed.), Longman, pp. 31-54.

18. Rural Development Programme 2014-2020. (2014), Warszawa, MARD.

EP 2015 (62) 4 (907-920) 
19. Sikorska A., Kowalski A., Karwat-Woźniak B., Goraj L., Chmieliński P. (2009): Instrumenty oddziaływania państwa na ksztaltowanie struktury obszarowej gospodarstw rolnych $w$ Polsce; rola systemu ubezpieczenia społecznego rolników $w$ ksztaltowaniu tej struktury. Stan obecny i rekomendacje na przyszłość oraz propozycje nowych rozwiqzań dotyczqcych tego obszaru dlasystemu ubezpieczeń społecznych. Warszawa, IERiGŻ-PIB,.

20. Social Diagnosis (2003): Warunki i jakość życia Polaków, J. Czapiński, T. Panek (eds.) Rada Monitoringu Społecznego, Wyższa Szkoła Finansów i Zarządzania, Warszawa, p. 93.

21. Social Diagnosis (2009): Warunki i jakość życia Polaków. J. Czapiński, T. Panek (eds.) Rada Monitoringu Społecznego, Wyższa Szkoła Finansów i Zarządzania, Warszawa, pp. 46-47.

22. Stasiak A. (1983): Struktury spoleczno-demograficzne wsi polskiej i jej przemiany in: Biuletyn KPZK PAN, 122, Warszawa, pp. 53-67.

23. Wójcik M. (2009): Społeczna geografia wsi, Czasopismo Geograficzne, Vol. 80, No. 1-2, PTG, Wrocław, pp. 42-62. 